\title{
Establishing a Gradient of Risk in Patients with Acute Coronary Syndromes Using Troponin I Measurements
}

\author{
Khalid Al-Harbi ${ }^{a}$ C.G. Suresh ${ }^{b}$ Mohammad Zubaid ${ }^{b}$ Abayomi O. Akanji ${ }^{a}$ \\ aDepartment of Pathology, Chemical Pathology Unit, b Department of Medicine, Division of Cardiology, \\ Kuwait University Faculty of Medicine and Mubarak Al-Kabeer Hospital, Kuwait
}

\section{Key Words}

Acute coronary syndromes - Myocardial infarction . Cardiac markers · Troponins . Unstable angina

\begin{abstract}
Objective: To evaluate the role of serum troponin I (Tnl) estimations in the early risk stratification of patients with acute coronary syndromes (ACS) subsequently diagnosed as acute myocardial infarction (AMI) or unstable angina (UA). Subjects and Methods: Blood samples were collected from 86 patients admitted to the Coronary Care Unit of the Mubarak Al-Kabeer Hospital, Kuwait, with a diagnosis of ACS on admission ( $\mathrm{Tnl}-1)$ and after $8 \mathrm{~h}(\mathrm{Tnl}-2)$ and $16 \mathrm{~h}$ (Tnl-3). Blood was also collected from 38 age-matched healthy controls for comparison. Serum Tnl was measured by paramagnetic particle chemiluminescent immunoassay. Results: Serum Tnl of $<0.05 \mathrm{ng} /$ $\mathrm{ml}$, corresponding to the 99th percentile, was established for healthy subjects. Patients diagnosed as UA had a 99th percentile Tnl-1 value of about $0.30 \mathrm{ng} / \mathrm{ml}$. The best specificity and sensitivity for ACS was obtained for Tnl-2; indeed, Tnl- $2>0.3 \mathrm{ng} / \mathrm{ml}$ gave a $>80 \%$ certainty of diagnosis of AMI. Also, Tnl- $2<0.3 \mathrm{ng} / \mathrm{ml}$ in ACS patients was approximately $80 \%$ sensitive for the diagnosis of UA but relatively nonspecific (approximately $40 \%$ ). Specificity for Tnl-2 for the diagnosis of UA improved to about $90 \%$ by narrowing the diagnostic range to $0.05-0.3 \mathrm{ng} /$
\end{abstract}

$\mathrm{ml}$. Tnl values in UA increased by $<100 \%$ at $8 \mathrm{~h}$, while in AMI, this increase was up to $1,000 \%$. Conclusion: In the evaluation of ACS, admission and 8-hour serum Tnl $<0.05 \mathrm{ng} / \mathrm{ml}$ is probably not cardiac in origin; serum $\mathrm{Tnl}$ $>0.3 \mathrm{ng} / \mathrm{ml}$ on admission and increasing rapidly by $8 \mathrm{~h}$ is likely $\mathrm{AMI}$, and serum $\mathrm{Tnl}>0.05$ and $<0.3 \mathrm{ng} / \mathrm{ml}$ on admission with a mild increase by $8 \mathrm{~h}$ is likely due to UA.

Copyright $@ 2002$ S. Karger AG, Basel

\section{Introduction}

The aim of risk stratification in acute coronary syndromes (ACS) is to identify those patients at greatest risk of recurrent ischemic events who might benefit from further investigation and management [1,2]. Typically, ACS is subdivided on clinical grounds into acute myocardial infarction (AMI) and unstable angina (UA) [2, 3]. The risk of cardiac death or significant disability differs significantly between these two cardiac disorders.

Most available cardiac markers can differentiate relatively easily between patients with noncardiac chest pain and those with AMI [4-6]. The major diagnostic dilemma is in patients with non-Q wave AMI and those with UA, in whom therapy is often indicated but is not as aggressive as in those with AMI [4-6]. In these individuals, there is also a need for awareness of their increased short- and

\begin{tabular}{ll}
\hline KARGER & ( ) 2002 S. Karger AG, Basel \\
Fax +4161306 1234 & 1011-7571/02/0111-0018\$18.50/0 \\
$\begin{array}{l}\text { E-Mail karger@karger.ch } \\
\text { www.karger.com }\end{array}$ & $\begin{array}{l}\text { Accessible online at: } \\
\text { www.karger.com/journals/mpp }\end{array}$
\end{tabular}

Prof. Abayomi O. Akanji

Department of Pathology, Kuwait University Faculty of Medicine

PO Box 24923

13110 Safat (Kuwait)

Tel. +965 531 9476, Fax +965 533 8905, E-Mail abayomi@hsc.kuniv.edu.kw 
long-term risk of AMI and/or sudden cardiac death. Their immediate need or otherwise for potentially expensive, complicated or dangerous intervention procedures such as angiography, angioplasty and stress testing also needs careful assessment.

There are numerous reports in the literature to the effect that serial cardiac troponin I (TnI) estimations can assist in the process of risk stratification in ACS [2-6]. These reports have essentially been from specialized cardiac centers in Europe and North America. It is important to establish such guidelines on the use of cardiac markers in other parts of the world, particularly since one of the important recommendations of the new European Society of Cardiology (ESC)/American College of Cardiology (ACC)/American Heart Association (AHA) guidelines [2, $3]$ is that different laboratories worldwide should establish their own cutoff points for clinical decision-making in ACS based on cardiac TnI estimations.

Coronary heart disease is the greatest cause of mortality in adults in Kuwait and other Arabian Gulf countries $[7,8]$. Its investigation and treatment also consumes a large percentage of the health care resources of these countries. Management guidelines therefore need to be optimized to be more cost-effective and based on the best evidence. This preliminary study was therefore designed to answer three specific questions in relation to the management of patients with chest pain in a tertiary care facility in Kuwait: (1) Can serial TnI estimations differentiate healthy control subjects from patients with ACS? (2) Can serial TnI estimations distinguish ACS patients with UA from those with AMI? (3) What proportions of UA patients have serial TnI values greater than the 99th percentile for the healthy population and therefore require more aggressive intervention measures?

\section{Subjects and Methods}

There were 2 groups of subjects. Group 1 consisted of 86 patients admitted to the Coronary Care Unit of the Mubarak Al-Kabeer Hospital, Kuwait, with a diagnosis of ACS. All the cases underwent full cardiological review and examination. Thirty-five of these subjects (aged $43-78$ years; 27 males, 8 females) were eventually diagnosed as having UA with the use of Braunwald's criteria [9] and the absence of ST segment abnormalities on ECG; 51 of the subjects (aged 37-88 years; 46 males, 5 females) proved to have AMI with classical clinical and $\mathrm{ECG}$ changes ( $\mathrm{Q}$ wave and non-Q wave).

Group 2 comprised 38 age-matched healthy controls (aged 48-77 years; 28 males, 10 females) who were ambulant and apparently healthy with no history of cardiovascular or any other chronic disease.

Blood samples were collected from the patients on admission to the unit (TnI-1) and subsequently, $8 \mathrm{~h}$ (TnI-2) and $16 \mathrm{~h}$ (TnI-3) after admission. Only baseline samples were collected from the healthy control subjects. Serum was extracted within $15 \mathrm{~min}$ of sample collection and analyzed immediately. When it was not possible to analyze the samples within $2 \mathrm{~h}$ of collection, they were stored frozen at $-20^{\circ} \mathrm{C}$. All analyses were, however, performed within $24 \mathrm{~h}$ of sample collection.

The serum TnI level was measured by a paramagnetic particle chemiluminescent immunoassay on a Beckman Access Analyzer. The intra- and interassay coefficients of variation for the serum TnI assays were always $<2.5 \%$. Specifically, the TnI assay was not influenced by uremia, in that in all 20 patients with chronic renal failure (and no evidence of ischemic heart disease) who were separately investigated, none had serum $\mathrm{TnI}>0.02 \mathrm{ng} / \mathrm{ml}$.

The laboratory was blind to the diagnosis and the cardiologists blind to the laboratory results during the course of the study. The data were analyzed by nonparametric methods with regards to the final cardiac diagnosis. Within-group differences between TnI, TnI-2 and TnI-3 levels were calculated using Wilcoxon signed rank tests. Between-group differences were explored by Mann-Whitney U tests. Statistical analyses were performed by computer using the procedures of the Statistical Package of the Social Sciences (SPSS-X, 1998). A p value $<0.05$ was considered statistically significant.

\section{Results}

The results obtained for TnI values are shown in table 1 . In the patients eventually diagnosed after full cardiological evaluation and hospital discharge or death as AMI or UA, the mean, median and range of values for TnI at presentation and also 8 and $16 \mathrm{~h}$ after admission are indicated in table 1 . Recruitment values for the healthy control subjects are also included.

Only 1 out of the $38(3 \%)$ healthy control subjects we studied had TnI values of $>0.1 \mathrm{ng} / \mathrm{ml}$ and even then, it was only $0.121 \mathrm{ng} / \mathrm{ml}$. Indeed, 32 of $38(84 \%)$ healthy subjects had values $<0.05 \mathrm{ng} / \mathrm{ml}$. The 99 th percentile value for TnI in our healthy population was estimated to be $0.05 \mathrm{ng} / \mathrm{ml}$. Therefore, in consonance with the recently published ESC/ACC/AHA guidelines [2, 3], an admission TnI value $>0.05 \mathrm{ng} / \mathrm{ml}$ should effectively exclude almost all healthy subjects with noncardiac chest pain in our population.

At presentation (TnI-1), $60 \%$ of the patients with AMI had TnI-1 levels $>0.05 \mathrm{ng} / \mathrm{ml}$ and $38 \%$ had levels $>0.30$ $\mathrm{ng} / \mathrm{ml}$. About $8 \mathrm{~h}$ later, $88 \%$ had $\mathrm{TnI}>0.05 \mathrm{ng} / \mathrm{ml}$ and $80 \%$ had $\mathrm{TnI}>0.30 \mathrm{ng} / \mathrm{ml}$. These values were essentially similar at $16 \mathrm{~h}(\mathrm{TnI}>0.05 \mathrm{ng} / \mathrm{ml}, 93 \%$; TnI $>0.3 \mathrm{ng} / \mathrm{ml}$, $87 \%)$. The median increase in TnI values from admission (TnI-1) to $8 \mathrm{~h}$ after admission (TnI-2) was about 1,020\%.

With respect to UA patients, at presentation (TnI-1), the 99th percentile of values was $0.28 \mathrm{ng} / \mathrm{ml} .38 \%$ of patients had TnI-1 levels $>0.05 \mathrm{ng} / \mathrm{ml}$ and $15 \%$ had levels $>0.30 \mathrm{ng} / \mathrm{ml}$; while $85 \%$ had values $<0.30 \mathrm{ng} / \mathrm{ml}$. About 
Table 1. TnI values in healthy control subjects and in patients with ACS on admission and 8 and $16 \mathrm{~h}$ after admission

\begin{tabular}{|c|c|c|c|c|c|}
\hline \multirow[t]{2}{*}{ Group } & & \multicolumn{3}{|c|}{ TnI levels, ng/ml } & \multirow{2}{*}{$\begin{array}{l}\text { Percentage } \\
\text { increase }^{1} \\
(\text { TnI-1/2) }\end{array}$} \\
\hline & & $\begin{array}{l}\text { presentation } \\
\text { (TnI-1) }\end{array}$ & $\begin{array}{l}8 \mathrm{~h} \\
(\mathrm{TnI}-2)\end{array}$ & $\begin{array}{l}16 \mathrm{~h} \\
(\mathrm{TnI}-3)\end{array}$ & \\
\hline $\begin{array}{l}\text { Controls } \\
(\mathrm{n}=38)\end{array}$ & $\begin{array}{l}\text { mean } \\
\text { median } \\
95 \% \mathrm{CI} \\
\text { range }\end{array}$ & $\begin{array}{l}0.033^{\mathrm{a}} \\
0.020 \\
0.006-0.108 \\
0.005-0.121\end{array}$ & & & \\
\hline $\begin{array}{l}\text { UA } \\
(n=35)\end{array}$ & $\begin{array}{l}\text { mean } \\
\text { median } \\
95 \% \mathrm{CI} \\
\text { range }\end{array}$ & $\begin{array}{l}0.146 \\
0.036 \\
0.000-1.031 \\
0.000-1.359\end{array}$ & $\begin{array}{l}0.371^{\mathrm{b}} \\
0.085 \\
0.003-2.315 \\
0.003-3.201\end{array}$ & $\begin{array}{l}0.360 \\
0.060 \\
0.002-2.756 \\
0.001-3.000\end{array}$ & 90 \\
\hline $\begin{array}{l}\text { AMI } \\
(n=51)\end{array}$ & $\begin{array}{l}\text { mean } \\
\text { median } \\
95 \% \mathrm{CI} \\
\text { range }\end{array}$ & $\begin{array}{l}0.970^{\mathrm{c}, \mathrm{d}} \\
0.069 \\
0.013-6.983 \\
0.011-7.484\end{array}$ & $\begin{array}{l}8.440 \\
2.156 \\
0.021-40.124 \\
0.010-43.000\end{array}$ & $\begin{array}{l}5.725 \\
1.700 \\
0.023-24.072 \\
0.000-30.313\end{array}$ & 1,018 \\
\hline
\end{tabular}

$\mathrm{CI}=$ Confidence interval.

a Different from 8- and 16-hour values for UA and AMI ( $\mathrm{p}<0.01)$; ${ }^{\mathrm{b}}$ different from admission value for UA $(p<0.001) ;{ }^{c}$ different from control and UA at presentation $(p<0.05)$; $\mathrm{d}$ different from 8- and 16-hour values for AMI $(\mathrm{p}<0.001)$.

1 Value of 0.00 considered as 0.001 for statistical purposes.

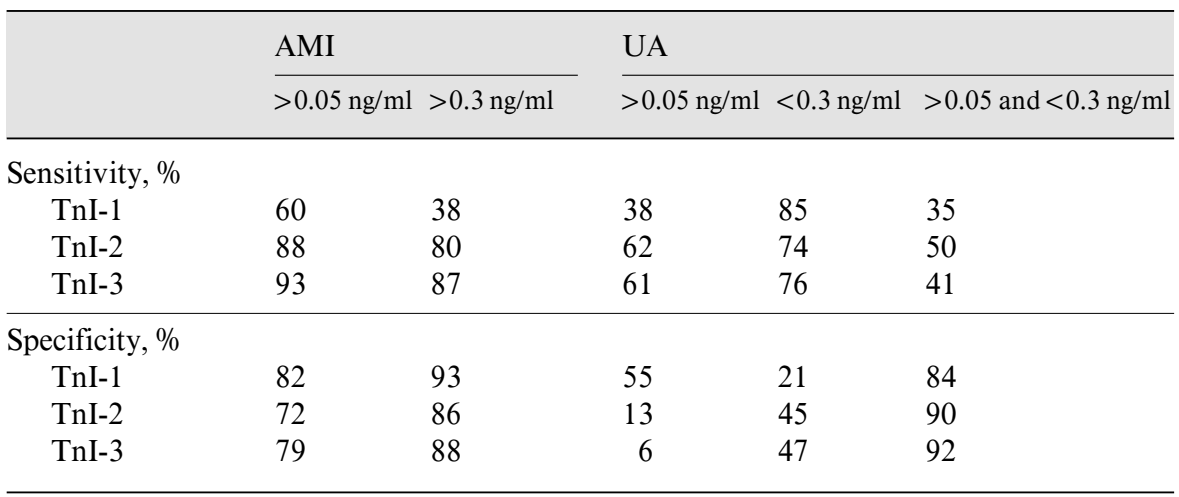

Table 2. Diagnostic sensitivity and specificity for TnI measurements in ACS
$8 \mathrm{~h}$ later, $62 \%$ had $\mathrm{TnI}>0.05 \mathrm{ng} / \mathrm{ml}$ and $26 \%$ had $\mathrm{TnI}$ $>0.30 \mathrm{ng} / \mathrm{ml} ; 74 \%$ had values $<0.30 \mathrm{ng} / \mathrm{ml}$. The values at $16 \mathrm{~h}$ were essentially similar to those at $8 \mathrm{~h}(\mathrm{TnI}>0.05$ $\mathrm{ng} / \mathrm{ml}, 61 \%$; TnI $>0.30 \mathrm{ng} / \mathrm{ml}, 24 \%$; TnI $<0.30 \mathrm{ng} / \mathrm{ml}$, $76 \%$ ). The median increase in TnI values from admission (TnI-1) to $8 \mathrm{~h}$ after admission (TnI-2) was about $90 \%$.

The sensitivity and specificity profiles at different cutoff points for the diagnosis of UA and myocardial infarction are indicated in table 2. This table utilizes the finding from the study that the upper cutoff point for healthy patients without ACS is $0.05 \mathrm{ng} / \mathrm{ml}$, and further- more that the 99th percentile for the patients subsequently diagnosed as having UA was about $0.30 \mathrm{ng} / \mathrm{ml}$. These cutoff point estimates were essentially similar to those derived from receiver operator characteristic curves plotted for the sensitivity and specificity of diagnosis of UA and AMI for different values of TnI on admission and 8 and $16 \mathrm{~h}$ later. It would appear that the best specificity and sensitivity for both acute coronary syndromes are obtainable for TnI-2, i.e. the 8-hour postadmission value (table 2). 


\section{Discussion}

In 1999, the US National Academy of Clinical Biochemistry [4] and the International Federation of Clinical Chemistry [5] independently recommended that cardiac troponin be the standard biomarker for detecting myocardial damage. More recently [2, 3], the ESC, ACC and AHA endorsed these recommendations and further suggested that classification of specific ACS should be based on blood troponin concentrations. Other important implications of these new recommendations are that myocardial injury short of myocardial infarction can be recognized, significant troponin elevations may indicate irreversible rather than reversible cardiac damage and different levels of serum cardiac troponin levels may signify a different prognosis in different patients with ACS [2,3]. In patients presenting with severe chest pain, it is important to immediately exclude noncardiac pain and identify those with an ACS. The latter is potentially life threatening, although it presents with a spectrum of clinical disorders ranging from AMI to the less immediately serious UA [10]. Treatments with clot lysis and antiplatelet therapy have reduced the morbidity and mortality rates of these syndromes but have to be properly targeted to reduce costs and associated complications; these treatments benefit those with clear-cut AMI but their role in those with UA is less clear. Furthermore, UA appears clinically heterogeneous with varying medium- to longterm cardiac risk. However, there is increasing evidence that the use of cardiac troponin measurements at specific time points after the onset of chest pain could assist in early stratification of ACS and institution of appropriate intervention measures [10-12].

The serum troponin level is believed to detect microinfarcts in patients with UA - hence its potential usefulness in the identification of patients with UA without ST segment elevation but at an increased risk for cardiac events, including AMI and cardiac death [10-13]. Furthermore, UA patients with elevated troponin levels tend to be refractory to conventional medical treatment, have a higher incidence of adverse cardiac events and show a poorer short-term (up to 30 days postevent) prognosis [14-17]. It has also been reported that troponin measurement up to 3-4 days after the acute event could give an indication of the long-term ( $>500$ days) prognosis of the ACS [18]. Indeed, the serum troponin level provides a valuable insight into the morphological basis of ACS, in that angiographic studies have shown that elevated troponin levels are more likely to be associated with the presence of complex atheromatous lesions and visible throm- bus formation $[14,17,19]$. The degree of elevation of troponin could also guide the preference for the specific pharmacological or other intervention modality, as with the use of enoxaparin [20], platelet receptor antagonists such as tirofiban and abcimixab [21,22] and procedures including coronary angioplasty, percutaneous transluminal coronary angioplasty, stent insertion, rotational atherectomy and stress testing [22-24].

This study, performed on patients with severe chest pain admitted to a coronary care facility in Kuwait, has established a diagnostic cutoff point of $0.05 \mathrm{ng} / \mathrm{ml}$ for healthy subjects. From the sensitivity and specificity profiles at different cutoff points for the diagnosis of UA and myocardial infarction indicated in table 2 , it would appear that the best specificity and sensitivity for both ACS are obtainable for TnI-2, i.e. the 8-hour postadmission value. An 8 -hour TnI value of $>0.30 \mathrm{ng} / \mathrm{ml}$ gives a $>80 \%$ certainty of diagnosis of AMI. Similarly, an 8-hour value of $<0.30 \mathrm{ng} / \mathrm{ml}$ in a patient with anginal-type chest pain is approximately $80 \%$ sensitive for the diagnosis of UA but is relatively nonspecific (approximately $40 \%$ ), because all healthy control subjects also had TnI values that fell into this category. Specificity for the 8-hour TnI value for the diagnosis of UA is, however, improved to about $90 \%$ by narrowing the diagnostic cutoff range to $0.05-0.30 \mathrm{ng} / \mathrm{ml}$, which effectively excludes all the healthy noncardiac patients. The other distinguishing feature for risk stratification is that TnI values in UA increase at best by $<100 \%$ $8 \mathrm{~h}$ after admission, and even then generally to less than $0.30 \mathrm{ng} / \mathrm{ml}$. In AMI, the median increase is $>1,000 \%$ and generally to much higher than $0.30 \mathrm{ng} / \mathrm{ml}$ (table 1).

In agreement with recently published reports $[14,17]$, up to $40-60 \%$ of our patients eventually diagnosed with UA had TnI values higher than $0.05 \mathrm{ng} / \mathrm{ml}$, the cutoff point for the normal healthy population, on admission and up to $16 \mathrm{~h}$ after admission. More worrying, though, is that up to $15-25 \%$ of those with UA had TnI values higher than $0.30 \mathrm{ng} / \mathrm{ml}$, a cutoff point we had identified for the diagnosis of AMI. It is therefore possible to establish a gradient of risk for UA, based on which, a protocol for the urgency of the need for aggressive intervention could be established. Using the TnI-2 values $8 \mathrm{~h}$ after admission, about $35 \%$ of those with UA have values $<0.05 \mathrm{ng} / \mathrm{ml}$ and could be safely discharged from the emergency department [25]. The next level includes the $50 \%$ or so of patients with values $>0.05$ and $<0.30 \mathrm{ng} / \mathrm{ml}$ - these require some degree of follow-up in the short or long term. The next level, corresponding to the greatest risk, is the $10-15 \%$ of patients with values $>0.30 \mathrm{ng} / \mathrm{ml}$ in whom more aggressive intervention is indicated. These figures 
could constitute the evidence base for long-term planning for the management of ACS in Kuwait.

\section{Conclusion}

In patients attending a cardiac unit in Kuwait for assessment of chest pain, and in association with clinical, ECG and other relevant data, serum $\mathrm{TnI}<0.05 \mathrm{ng} / \mathrm{ml}$ on admission and $8 \mathrm{~h}$ after admission is probably not cardiac in origin; serum TnI $>0.30 \mathrm{ng} / \mathrm{ml}$ on admission and increasing rapidly (up to 10 -fold) $8 \mathrm{~h}$ after admission is most likely due to AMI. When serum TnI is $>0.05$ and
$<0.30 \mathrm{ng} / \mathrm{ml}$ on admission and increases slightly if at all $8 \mathrm{~h}$ after admission, the patient likely has UA. With regards to the latter, up to $15 \%$ could have values similar to those described for AMI and require aggressive intervention procedures.

\section{Acknowledgments}

The technical assistance of Dr. Praveen Kumar and Ms. Aisha Hussein is gratefully acknowledged. We also thank our colleagues on the medical staff of the Clinical Chemistry and Cardiology Units of Mubarak Al-Kabeer Hospital, Kuwait, for their support and encouragement.

\section{References}

1 Timmis A: Acute coronary syndromes: Risk stratification. Heart 2000;83:241-246.

2 Apple FS, Wu AH: Myocardial infarction redefined: Role of cardiac troponin testing. Clin Chem 2001;47:377-379.

3 Myocardial infarction redefined - a consensus document of The Joint European Society of Cardiology/American College of Cardiology Committee for the redefinition of myocardial infarction. J Am Coll Cardiol 2000;36:959969.

4 Wu AH, Apple FS, Gibler WB, Jesse RL, Warshaw MM, Valdes R Jr: National Academy of Clinical Biochemistry Standards of Laboratory Practice: Recommendations for the use of cardiac markers in coronary artery diseases. Clin Chem 1999;45:1104-1121.

5 Panteghini M, Apple FS, Christenson RH, Dati F, Mair J, Wu AH: Use of biochemical markers in acute coronary syndromes. IFCC Scientific Division, Committee on Standardization of Markers of Cardiac Damage. International Federation of Clinical Chemistry. Clin Chem Lab Med 1999;37:687-693.

6 Collinson PO: Cardiac markers into the new millennium. Ann Clin Biochem 2000;37:109113.

7 Al-Adsani A, Memon A, Peneva A, Baidas G: Clinical epidemiology of acute myocardial infarction in Kuwait. Acta Cardiol 2000;55:1723.

8 Ministry of Health, Kuwait: Cardiovascular Mortality and Morbidity in Kuwait (19801993). Kuwait, Health and Vital Statistics Division, Ministry of Health, 1994.

9 Braunwald E: Unstable angina: A classification. Circulation 1989;80:410-414.

10 Hamm CW: Risk stratifying acute coronary syndromes: Gradient of risk and benefit. Am Heart J 1999;138:S6-11.
11 Stubbs P, Collinson P, Moseley D, Greenwood $\mathrm{T}$, Noble M: Prognostic significance of admission troponin $\mathrm{T}$ concentrations in patients with myocardial infarction. Circulation 1996;94: 1291-1297.

12 Stubbs P, Collinson P, Moseley D, Greenwood T, Noble M: Prospective study of the role of troponin $\mathrm{T}$ in patients admitted with unstable angina. BMJ 1996;313:262-264.

13 Ohman EM, Armstrong PW, Christenson RH, Granger CB, Katus HA, Hamm CW, O'Hanesian MA, Wagner GS, Kleiman NS, Harrell FE Jr, Califf RM, Topol EJ: Cardiac troponin T levels for risk stratification in acute myocardial ischemia. GUSTO IIA Investigators. N Engl J Med 1996;335:1333-1341.

14 Heeschen C, Goldmann BU, Terres W, Hamm $\mathrm{CW}$ : Cardiovascular risk and therapeutic benefit of coronary interventions for patients with unstable angina according to the troponin $\mathrm{T}$ status. Eur Heart J 2000;21:1159-1166.

15 Kontos MC, Anderson FP, Alimard R, Ornato JP, Tatum JL, Jesse RL: Ability of troponin I to predict cardiac events in patients admitted from the emergency department. J Am Coll Cardiol 2000;36:1818-1823.

16 Leowattana W, Mahanonda N, Bhuripanyo K, Pokum S, Kiartivich S: Serum cardiac troponin $\mathrm{T}$ in unstable angina pectoris patients. $\mathrm{J}$ Med Assoc Thai 2000;83(suppl 2):S61-S65.

17 Kane GR, Keshavamurthy CB, Sethi RB, Mathew R: Troponin-T in unstable angina - a clinical and angiographic study. J Assoc Physicians India 2000;48:1074-1077.

18 Kanna M, Nonogi H, Sumida H, Miyazaki S, Daikoku S, Morii I, Yasuda S, Sutani Y, Baba T, Goto Y: Usefulness of serum troponin T levels on day three or four in predicting survival after acute myocardial infarction. Am J Cardiol 2001;87:294-297.

19 Newby LK, Christenson RH, Ohman EM, Armstrong PW, Thompson TD, Lee KL, Hamm CW, Katus HA, Cianciolo C, Granger CB, Topol EJ, Califf RM: Value of serial tro- ponin $\mathrm{T}$ measures for early and late risk stratification in patients with acute coronary syndromes. The GUSTO-IIa Investigators. Circulation 1998;98:1853-1859.

20 Morrow DA, Antman EM, Tanasijevic M, Rifai $\mathrm{N}$, de Lemos JA, McCabe $\mathrm{CH}$, Cannon $\mathrm{CP}$, Braunwald E: Cardiac troponin I for stratification of early outcomes and the efficacy of enoxaparin in unstable angina: A TIMI-11B substudy. J Am Coll Cardiol 2000;36:1812-1817.

21 Heeschen C, Hamm CW, Goldmann B, Deu A, Langenbrink L, White HD: Troponin concentrations for stratification of patients with acute coronary syndromes in relation to therapeutic efficacy of tirofiban. PRISM Study Investigators. Platelet Receptor Inhibition in Ischemic Syndrome Management. Lancet 1999;354: 1757-1762.

22 Hamm CW, Heeschen C, Goldmann B, Vahanian A, Adgey J, Miguel CM, Rutsch W, Berger J, Kootstra J, Simoons ML: Benefit of abciximab in patients with refractory unstable angina in relation to serum troponin $\mathrm{T}$ levels. c7E3 Fab Antiplatelet Therapy in Unstable Refractory Angina (CAPTURE) Study Investigators. N Engl J Med 1999;340:1623-1629.

23 Harris BM, Nageh T, Marsden JT, Thomas MR, Sherwood RA: Comparison of cardiac troponin $\mathrm{T}$ and $\mathrm{I}$ and $\mathrm{CK}-\mathrm{MB}$ for the detection of minor myocardial damage during interventional cardiac procedures. Ann Clin Biochem 2000; 37:764-769.

24 Fleming SM, Divilly M, Chakravarthi PI, Grimes H, Daly K: The role of cardiac troponin $\mathrm{I}$ in determining the necessity for exercise electrocardiography in low risk patients with chest pain. Ir J Med Sci 2000;169:173-175.

25 Collinson PO, Premachandram S, Hashemi K: Prospective audit of incidence of prognostically imporant myocardial damage in patients discharged from emergency department. BMJ 2000;320:1702-1705. 